\title{
DIALÉTICA DO "PRAZER E SOFRIMENTO": A RELAÇÃO DE MESTRANDOS E DOUTORANDOS COM SEU TRABALHO ACADÊMICO
}

\author{
DIALECTIC OF "PLEASURE AND SUFFERING": THE \\ RELATIONSHIP OF MASTER'S AND DOCTORAL STUDENTS \\ WITH THEIR ACADEMIC WORK
}

\author{
DIALÉCTICA DE LO "PLACER Y SUFRIMIENTO": LA \\ RELACIÓN ENTRE ESTUDIANTES DE MAESTRÍA Y DE \\ DOCTORADO CON SU TRABAJO ACADÉMICO
}

\section{Camila Cristina Rodrigues Salgado \\ Doutora pela Universidade Federal do Rio Grande do Norte, Natal, Brasil \\ Professora da Universidade Federal da Paraíba (DCSA), Bananeiras, Brasil. \\ adm.camilarodrigues@hotmail.com \\ Renan Felinto de Farias Aires \\ Doutor pela Universidade Federal do Rio Grande do Norte, Natal, Brasil \\ Professor da Universidade Federal Rural do Semi-Árido (DCSA), Mossoró, Brasil. \\ renanffa@hotmail.com}

\author{
Fernanda Julyanna Silva dos Santos \\ Doutora pela Universidade Federal do Rio \\ Grande do Norte, Natal, Brasil \\ Professora da Universidade Federal do Rio \\ Grande do Norte (ESUFRN), Natal, Brasil. \\ fernandajusa@gmail.com
}

\author{
Contextus \\ ISSNe 2178-9258 \\ Organização: Comitê Científico Interinstitucional \\ Editor Científico: Diego de Queiroz Machado \\ Editor Executivo: Carlos Daniel Andrade \\ Recebido Avaliação: double blind review pelo \\ SEER/OJS em 25/08/2017 \\ Aceito em 19/04/2018 \\ $2^{2}$ versão aceita em 30/05/2018
}

\begin{abstract}
RESUMO
A relação de trabalho dentro da sociedade se apresenta como elemento fundamental por meio do qual o homem se estrutura psiquicamente, podendo resultar em prazer e/ou sofrimento, objeto de estudo da psicodinâmica do trabalho. Nesse campo, percebe-se uma lacuna relativa à exploração da dialética prazer-sofrimento no cenário acadêmico quanto à comparação entre mestrandos e doutorandos. Este estudo objetiva compreender a subjetividade da relação de prazer e sofrimento, de mestrandos e doutorandos em administração, com seu trabalho acadêmico. Para isso, realizaram-se entrevistas focalizadas, posteriormente codificadas e analisadas qualitativamente por meio de análise de conteúdo. Como resultados, observou-se que os mestrandos apontaram o sentimento de desprazer como principal fonte de sofrimento e o crescimento profissional como principal fonte de prazer. Os doutorandos, por sua vez, também apontaram o sentimento de desprazer como principal fonte de sofrimento, porém o relacionamento interpessoal no trabalho se destacou como principal fonte de prazer.

Palavras-chave: Psicodinâmica do trabalho; Subjetividade; Dialética prazer-sofrimento; Mestrandos;

Doutorandos.
\end{abstract}

\section{ABSTRACT}

The work relationship within society shows itself as a fundamental element by means of which man is structured psychologically and may result in pleasure and/or suffering, which is an object of study for the psychodynamics of work. In this field, a gap is noticed in exploring the pleasure-suffering dialectic within the academic scenario regarding the comparison between master's and doctoral students. This study aims to understand the subjectivity 
in the pleasure and suffering relationships of administration masters' and doctoral students with their academic work. For this, focused interviews were carried out and then coded and analyzed qualitatively by means of content analysis. As a result, the masters' students were observed to point at the feeling of displeasure as the source of suffering and at professional growth as the source of pleasure. Doctoral students, in turn, also indicated displeasure as the source of suffering, but interpersonal relationships at work stood out as the source of pleasure.

Keywords: Psychodynamic of work; Subjectivity; Pleasure-suffering dialectic; Masters students; Doctoral students.

\section{RESUMEN}

La relación de trabajo dentro de la sociedad se presenta como un elemento fundamental por el cual el hombre si estructura psíquicamente y puede resultar en el placer y/o sufrimiento, objeto de estudio de la psicodinámica del trabajo. En este campo, si ve una brecha en la exploración de la dialéctica placer-sufrimiento en el ámbito académico en lo que respecta a comparar estudiantes de maestria y de doctorado. Este estudio tiene como objetivo comprender la subjetividad de la relación de sufrimiento y placer de los estudiantes de maestría y de doctorado en administración con su trabajo académico. Para eso, se realizaron entrevistas enfocadas, posteriormente codificadas y analizadas cualitativamente mediante análisis de contenido. Como resultado, se observó que los estudiantes de maestria señalaron la sensación de desagrado como la principal fuente de sufrimiento y el crecimiento profesional como fuente principal de placer. Los estudiantes de doctorado, a su vez, también observaron la sensación de desagrado como la principal fuente de sufrimiento, pero las relaciones interpersonales en el trabajo se destacaron como la principal fuente de placer.

Palabras clave: Psicodinámica del trabajo; Subjetividad; Dialéctica placer-sufrimiento; Estudiantes de maestria; Estudiantes de doctorado.

\section{INTRODUÇÃO}

O trabalho dentro da sociedade se apresenta como meio fundamental para o homem não apenas produzir e sobreviver, mas também realizar-se e estruturar-se psiquicamente. A relação entre esses aspectos subjetivo e coletivo pode resultar em prazer e/ou sofrimento, objetos de estudo da psicodinâmica do trabalho.

De forma geral, o sofrimento na atividade profissional começa quando, apesar de seu zelo, o trabalhador não consegue dar conta da tarefa. Por sua vez, o prazer começa quando, graças a seu zelo, o trabalhador consegue inventar soluções convenientes, daí se poder dizer nesse contexto que prazer e sofrimento, em vez de suplementos de alma, são elementos estritamente indissociáveis do trabalho (DEJOURS, 2012). Este, assim, transita em território ambivalente, podendo tanto dar origem a processos de alienação ou descompensação psíquica, quanto ser fonte de saúde e instrumento de emancipação (TSCHIEDEL; MONTEIRO, 2013).

A preocupação com os efeitos do desempenho no trabalho sobre o sujeito e com a geração de prazer ou sofrimento não é um tema novo na literatura. A psicodinâmica do trabalho trouxe consideráveis contribuições teórico-metodológicas para o campo da psicologia do trabalho, encontrando bases na abordagem dejouriana, na medida em que reforçou a centralidade do trabalho na compreensão não apenas da doença, mas também da saúde e do prazer (BOUYER, 2010). 
Essa abordagem tem sido aplicada em diversas áreas com o intuito de compreender a dialética prazer-sofrimento, destacando-se os trabalhos desenvolvidos nos campos da música (ASSIS; MACEDO, 2008), do atendimento ao público (FERREIRA; MENDES, 2001), da segurança penitenciária (TSCHIEDEL; MONTEIRO, 2013) e da saúde (KESSLER; KRUG, 2012; MARTINS; ROBAZZI; BOBROFF, 2010; SOUZA; FERREIRA, 2010).

$\mathrm{Na}$ área da educação, registram-se os estudos de Bottega e Merlo (2010), com educadores sociais, o de Silva, F.G. (2011), com professores, o de Martins e Honório (2014), com docentes de uma instituição de ensino superior privada de Belo Horizonte, e o de Boas e Morin (2014), que objetivou analisar, em termos de saúde mental, as principais diferenças no trabalho entre professores de universidades brasileiras e canadenses. Além desses, o estudo de Bispo e Helal (2013), que realizou uma investigação com acadêmicos de um mestrado sobre o prazer e sofrimento na execução das suas tarefas, tratou de um tema ainda pouco debatido.

Nesse contexto, considerando a lacuna existente quanto à exploração da dialética prazersofrimento no cenário acadêmico e sabendo que ainda não há estudos buscando entender como a subjetividade da relação prazer e sofrimento de mestrandos difere e/ou se assemelha à de doutorandos na execução de seu trabalho acadêmico, o presente estudo se propõe responder à seguinte questão: como se dá a subjetividade da relação de prazer e sofrimento de mestrandos e doutorandos no desempenho de seu trabalho acadêmico?

Cabe destacar que a tarefa desenvolvida por mestrandos e doutorandos é aqui entendida como o trabalho desenvolvido por eles, ou seja, uma atividade que implica o saber-fazer - nesse caso, com foco no "aprender a fazer", bem como no engajamento do corpo, na mobilização da inteligência, bem como na capacidade de refletir, de interpretar e de reagir às situações (DEJOURS, 2004).

Diante disso, este trabalho tem como objetivo compreender a subjetividade da relação de prazer e sofrimento de mestrandos e doutorandos em administração com seu trabalho acadêmico. Para tanto, o artigo está estruturado da seguinte forma: em primeiro lugar, discute a subjetividade no trabalho; depois aborda a psicodinâmica do trabalho, tecendo breves considerações acerca do tema central; em seguida, discute a dialética do prazer e sofrimento, esmiuçando seus aspectos principais; depois apresenta, respectivamente, os aspectos metodológicos e a análise de resultados. Nas considerações finais, aponta os principais achados do estudo. 


\section{REFERENCIAL TEÓRICO}

\subsection{Subjetividade e trabalho}

A subjetividade é um conceito sem consenso a respeito de seu significado, apesar de bastante difundido na área da psicologia. Considerando os aspectos referentes apenas ao sujeito, Prado Filho e Martins (2007) caracterizam a subjetividade como uma produção de forças que o atravessam. Por sua vez, Sznelwar, Uchida e Lancman (2011) a consideram como um conjunto de fenômenos psíquico e de consciência que o sujeito relaciona consigo.

Ademais, Ramminger e Nardi (2008) analisam a subjetividade como uma experiência de "ser sujeitos", ou seja, ao mesmo tempo em que é submetido a uma ação, esse ser realiza uma outra ação dentro, de um tempo e de um contexto, carregando um conceito individual e social. Para os autores, o trabalho deve ser analisado considerando a maneira como os sujeitos vivenciam e dão sentido às suas experiências de trabalho, apontando como diferentes processos produtores de subjetividade variam em função dos contextos social, histórico e econômico.

Essas proposições convergem para a compreensão da subjetividade como um processo de interação entre o indivíduo e seu meio (REY, 1997). Constata-se, portanto, que a subjetividade deve ser compreendida como uma noção distinta da individualidade, já que ela é essencialmente social, caracterizando-se como um processo mental e íntimo que expressa intencionalidade, indica autonomia e autodesenvolvimento, reflexão e posicionamento crítico em relação à realidade, estabelecendo, concomitantemente, identidade e noção de alteridade (SCOZ, 2008; SILVA; SANTOS, 2011).

Diante do exposto, considera-se que o sujeito interpreta sua realidade de trabalho, reagindo física, mental e afetivamente, assim como a realidade também produz alterações no sujeito, resultando em um processo em que a realidade psíquica e a realidade de trabalho constituem a subjetividade desse trabalhador, ou seja, a construção articulada entre o psíquico e o social (ANTLOGA; MENDES, 2009). Dito de forma simples, o processo de subjetivação no trabalho pode ser entendido como o meio pelo qual o trabalhador atribui sentido em relação à sua realidade de trabalho, expresso pelos modos de pensar, sentir e agir de maneira individual ou coletiva (HOFFMANN; TRAVERSO; ZANINI, 2014).

Nesse contexto, para a subjetividade, trabalhar representa uma provação que a transforma ou, em outras palavras, trabalhar consiste não somente em produzir, mas também 
em transformar a si mesmo. No melhor dos casos, é uma ocasião oferecida à subjetividade para testar-se e até mesmo realizar-se (DEJOURS, 2004).

O trabalho, por sua vez, tem sido caracterizado de diferentes formas. Inicialmente, sua conceituação foi marcada por uma dissociação da relação com o desenvolvimento de afetos, tendo como foco unicamente a capacidade de trabalhar do indivíduo (SZNELWAR et al., 2011). O termo também já significou um fardo ou sacrifício, mas - com o advento do Renascimento passou a ser entendido como fonte de identidade e liberdade, bem como de desenvolvimento e autorrealização humana (LANCMA; UCHIDA, 2003; SOUZA; RIBEIRO, 2009).

Para Dejours (2004), trabalhar é engajar-se pessoalmente para responder a uma tarefa desenhada por pressões de cunho material e social, o que indica a importância do trabalho tanto na vida material quanto na social. Nessa perspectiva, Sznelwar et al. (2011) propõem que se aborde o trabalho com base em como os sujeitos o constroem e vivenciam, possibilitando assim enriquecer as diferentes representações sociais sobre ele.

Conforme Veronese (2009), a abordagem teórica entre a subjetividade e o trabalho torna-se relevante na medida em que o trabalho desempenha um papel importante sobre os processos de constituição das identidades. Para a autora, a maneira como cada pessoa atribui significado e sentido à sua relação com o trabalho se dá de forma singular, porém considerando o registro coletivo.

Isso posto, o trabalho assume diversos sentidos, como um modo peculiar e singular de o indivíduo produzir, realizar-se, sobreviver e estruturar-se psiquicamente. Os sentidos são atribuídos com base na relação que o trabalhador estabelece com os modos de organizar sua atividade profissional, que podem oferecer condições e oportunidades específicas (ANTLOGA; MENDES, 2009). O fato é que as diferentes situações de trabalho associadas às características pessoais dos trabalhadores e à rigidez na organização do trabalho podem revelar-se como carga psíquica, representada como a resultante da confrontação entre os desejos do trabalhador e da empresa (SILVA, N.R., 2011). Contudo, essa carga é difícil de ser quantificada, assim como comporta elementos afetivos e relacionais, revelando-se como um regulador da carga global presente no trabalho (DEJOURS, 1994).

O Quadro 1 apresenta uma breve síntese sobre os principais constructos teóricos trabalhados sobre a subjetividade e trabalho. 
Quadro 1 - Principais constructos teóricos sobre a subjetividade e trabalho

\begin{tabular}{|c|c|c|}
\hline $\begin{array}{l}\text { Constructo } \\
\text { teórico }\end{array}$ & Conceitos-chave & Principais autores \\
\hline \multirow{4}{*}{$\begin{array}{c}\text { Subjetividade e } \\
\text { Trabalho }\end{array}$} & $\begin{array}{l}\text { Produção de forças que atravessam o } \\
\text { sujeito }\end{array}$ & \multirow{4}{*}{$\begin{array}{c}\text { Ramminger e Nardi (2008); } \\
\text { Prado Filho e Martins (2007); } \\
\text { Sznelwar et al. (2011); } \\
\text { Lancma e Uchida (2003); } \\
\text { Souza e Ribeiro (2009); } \\
\text { Ribeiro e Léda (2004); } \\
\text { Dejours (2004); Veronese } \\
\text { (2009); } \\
\text { Rey (1997); } \\
\text { Scoz (2008); Silva e Santos } \\
\text { (2011); Antloga e Mendes } \\
\text { (2009). }\end{array}$} \\
\hline & $\begin{array}{l}\text { Como os sujeitos constroem e } \\
\text { vivenciam o seu trabalho, } \\
\text { possibilitando assim enriquecer as } \\
\text { diferentes representações sociais sobre } \\
\text { o trabalho }\end{array}$ & \\
\hline & $\begin{array}{l}\text { O trabalho desempenha um papel } \\
\text { importante sobre os processos de } \\
\text { constituição das identidades }\end{array}$ & \\
\hline & Processo essencialmente social & \\
\hline
\end{tabular}

Fonte: elaborado pelos autores (2015).

As questões referentes à relação entre sujeito, subjetividade e trabalho são abordadas dentro da teoria da psicodinâmica do trabalho, passível de ser definida como a análise dos processos intersubjetivos mobilizados pela situação do trabalho (SZNELWAR et al., 2011). A seção 1.2 discute essa teoria.

\subsection{Psicodinâmica do trabalho}

Teoria consolidada com base nas pesquisas de Christophe Dejours, a psicodinâmica do trabalho compreende o ser humano ativo profissionalmente na sua relação com os outros indivíduos e com a coletividade, pressupondo que o trabalho se situa como operador fundamental de construção do próprio sujeito, mediando inconsciente e campo social (GOMES; OLIVEIRA, 2013). Assim, tal abordagem visa ao coletivo e não aos indivíduos isoladamente, pois considera não existir um sujeito isolado, mas sim um que se constitui numa relação intersubjetiva da qual o trabalho é elemento indissociável (MERLO; MENDES, 2009; SZNELWAR et al., 2011).

Destaca-se, portanto, que a investigação à luz da psicodinâmica do trabalho coloca como questão central os conflitos decorrentes do encontro entre um sujeito, portador de uma história singular preexistente a este encontro, e uma situação de trabalho, cujas características são fixadas independentemente de sua vontade (MOLINIER, 2008). Nessa perspectiva, ela busca estudar dimensões menos visíveis da experiência de trabalho, tais como: mecanismos de cooperação, reconhecimento, sofrimento, mobilização da inteligência, vontade, motivação e 
estratégias defensivas que se desenvolvem e se estabelecem a partir das situações profissionais (HELOANI; LANCMAN, 2004; CASTRO; TOLEDO; ANDERY, 2010).

Antloga e Mendes (2009) distinguem três fases distintas pelas quais a psicodinâmica passou: a) a primeira contempla os trabalhos desenvolvidos na década de 1980, fundamentados no estudo do sofrimento psíquico, bem como na sua origem e nas transformações resultantes do confronto entre psiquismo do trabalhador e organização do trabalho; b) a segunda fase, que permanece até o início da década de 90, inicia a abordagem do prazer no trabalho e, consequentemente, se direciona para a saúde; e c) a terceira etapa enfoca o trabalho como locus de construção da identidade do trabalhador, explorando também a dinâmica do reconhecimento e as vivências de prazer e sofrimento frente às novas estruturas de organização do trabalho.

De forma geral, Dejours (1992) constrói o pressuposto de que a organização do trabalho exerce, sobre o homem, uma ação específica com impacto sobre o aparelho psíquico. Ao contrário de postular o trabalho como fator fundamentalmente enlouquecedor, conforme o título pode sugerir, ele afirma que os trabalhadores não se mostravam passivos em face das exigências e pressões organizacionais, mas capazes de se proteger dos efeitos nefastos à saúde mental.

Para Athayde (2005), essa obra levou Dejours a deslocar seu foco investigativo das doenças mentais geradas pelo trabalho para o sofrimento e as defesas contra esse sofrimento. Ainda segundo a análise do autor, à medida que a maioria dos trabalhadores conseguia conjurar a loucura, apesar da violência da organização do trabalho, a normalidade (equilíbrio instável, precário, entre sofrimento e defesas) é que se configurava como enigma. Em síntese, a proposta que permeia toda a obra não é a de criar novos homens, mas encontrar soluções que permitissem pôr fim à desestruturação de certo número deles, pelo trabalho (ABRAHÃO, 1990).

Ainda sobre o tema, Dejours (2012) atualiza as diretrizes da psicodinâmica do trabalho, reafirmando o caráter central inegociável da subjetividade na prática laboral. Para Dal Forno (2015), o fio condutor da obra é a hipótese de que trabalhar passa, diante dos desafios da realidade, por criar soluções além da prescrição de tarefas. Em outras palavras, trabalhar seria enfrentar criativamente o real onde o protocolo não funciona e, com isso, construir alternativas por meio da inteligência inventiva, sempre subjetiva, transformando e realidade e saindo, também, transformado. O trabalho vivo caracteriza-se, portanto, pela resistência ao fracasso e pela capacidade de demonstrar obstinação no confronto com o real que o protocolo não alcança (DEJOURS, 2012).

Percebe-se então que a psicodinâmica do trabalho tem aprofundado, há mais de três 
décadas, o papel do trabalho na relação saúde-adoecimento com base na análise dinâmica do cotidiano profissional e no pressuposto de que este exerce a função de mediador estruturante do psiquismo humano, ao permitir ao trabalhador que consolide sua identidade, seja pelo reconhecimento social, seja pela retribuição simbólica do engajamento profissional (SANTOS JÚNIOR; MENDES; ARAUJO, 2009). Ela se interessa pelas vivências subjetivas e pela intersubjetividade que permeia o trabalho e o lugar por este ocupado nos processos de regulação psíquica (DEJOURS; ABDOUCHELI; JAYET, 1994).

Portanto, considerando que a psicodinâmica do trabalho tem por objeto os processos intersubjetivos que tornam possível gerir socialmente as interpretações do trabalho pelos indivíduos, sua análise sugere que a retribuição esperada pelo indivíduo seja fundamentalmente de natureza simbólica, ou seja, baseada no reconhecimento da realidade que representa a contribuição individual, no sentido de gratidão (ASSIS; MACEDO, 2008).

De maneira geral, o trabalhar, para a psicodinâmica, pressupõe que o trabalhador impulsinoe sua personalidade para dar resposta a uma tarefa prescrita e formatada por pressões materiais e sociais, mobilizando a sua subjetividade em prol do alcance das metas impostas (SANTOS JÚNIOR; MENDES; ARAUJO, 2009). Desse modo, a psicodinâmica do trabalho se opõe a visões deterministas que colocam os trabalhadores no lugar de meros observadores passivos e impotentes de um mundo perverso, pois considera que, ao criar um espaço público de discussão, é possível impulsionar uma maior democracia das relações de trabalho e vislumbrar organizações mais propícias à saúde e à realização (TRAESEL; MERLO, 2011).

Nessa conjuntura, a psicodinâmica do trabalho também é marcada por ter se desenvolvido a partir da descoberta de estratégias coletivas de defesa nos ambientes de trabalho, por meio da cooperação para lutar contra o medo gerado pelos riscos da atividade (MOLINIER, 2008). Conforme destacam Anchieta et al. (2011), à luz da psicodinâmica do trabalho, pode-se enfrentar o sofrimento com estratégias de mediação voltadas a evitar a desestruturação e as desordens mentais dos trabalhadores, por meio seja da chamada mobilização subjetiva ou coletiva, que se esforça para construir soluções, seja das estratégias defensivas, que permitem proteger o ego contra dissonâncias cognitivas e afetos dolorosos.

Portanto, a psicodinâmica do trabalho amplia o conhecimento dos limites entre normalidade e patologias, tomando como objetos as defesas e estratégias defensivas que vieram preencher um espaço antes enigmático das articulações entre o singular e o coletivo, no contexto pautado pelo trabalho enquanto mediador essencial (BOUYER, 2010). Em outras palavras, 
sabendo que o contexto de trabalho pode ser reconhecido como fonte de construção da identidade e prazer, assim como como fonte de alienação e sofrimento, a psicodinâmica introduz o "saudável" como resultante de um compromisso entre sofrimento e estratégias de defesa (HOFFMANN; TRAVERSO; ZANINI, 2014).

Sobre todo o exposto, o Quadro 2 apresenta uma breve síntese sobre os principais constructos teóricos relacionados à psicodinâmica.

Quadro 2 - Principais constructos teóricos sobre a psicodinâmica do trabalho

\begin{tabular}{|c|c|c|}
\hline $\begin{array}{l}\text { Constructo } \\
\text { teórico }\end{array}$ & Conceitos-chave & Principais autores \\
\hline \multirow{4}{*}{$\begin{array}{l}\text { Psicodinâmica do } \\
\text { trabalho }\end{array}$} & Sofrimento psíquico & \multirow{4}{*}{$\begin{array}{c}\text { Gomes e Oliveira (2013); Merlo } \\
\text { e Mendes (2009); Sznelwar et } \\
\text { al. (2011); Antloga e Mendes } \\
\text { (2009); Santos Júnior, Mendes e } \\
\text { Araujo (2009); Torres e Abrahão } \\
\text { (2006); Assis e Macedo (2008); } \\
\text { Ferreira e Mendes (2001); } \\
\text { Molinier (2008); Anchieta et al. } \\
\text { (2011); Bouyer (2010); } \\
\text { Hoffmann, Traverso e Zanini } \\
\text { (2014). }\end{array}$} \\
\hline & Prazer no trabalho & \\
\hline & $\begin{array}{l}\text { Enfoque no trabalho como locus de } \\
\text { construção da identidade do } \\
\text { trabalhador; dinâmica do } \\
\text { reconhecimento e vivências de } \\
\text { prazer e sofrimento frente às novas } \\
\text { estruturas de organização do } \\
\text { trabalho }\end{array}$ & \\
\hline & Estratégias coletivas de defesa & \\
\hline
\end{tabular}

Fonte: elaborado pelos autores (2015).

Nesse cenário, abre-se espaço para introduzir a discussão sobre a dialética entre prazer e sofrimento, que representa uma vivência subjetiva do trabalhador, compartilhada coletivamente e influenciada pela atividade de trabalho (FERREIRA; MENDES, 2001). Na perspectiva de Dejours e Abdoucheli (1994), o campo da psicodinâmica do trabalho volta-se para a relação psíquica dos trabalhadores com o trabalho, partindo das consequências deste sobre sua saúde mental, as quais podem ter natureza quer nefasta - quando o trabalho é patogênico -, quer favorável, quando o trabalho é estruturador. Essa dialética é o foco central do presente estudo, e receberá maior atenção na seção 1.3.

\subsection{Prazer e sofrimento}

Segundo Antloga e Mendes (2009), no modelo teórico da psicodinâmica do trabalho, todo trabalho pressupõe uma carga psíquica, resultado da confrontação do desejo do trabalhador com a realidade da organização do trabalho, assim como da pressão atribuída pela organização do trabalho ao aparelho psíquico do profissional. Dessa forma, ainda de acordo com os autores, 
quando permite a redução da carga psíquica e um funcionamento livre do psiquismo, o trabalho se torna fonte de gratificação; em contrapartida, quando não oferece espaço para articular os desejos do trabalhador e a realidade, o trabalho resulta em acúmulo ou bloqueio da energia psíquica, sendo uma fonte de tensão e sofrimento.

Portanto, todo o trabalho veicula implicitamente um custo humano expresso sob a forma de carga de trabalho, e as vivências de prazer-sofrimento têm como um dos resultados o confronto do sujeito com essa carga que, por conseguinte, tem impacto no seu bem-estar psíquico (FERREIRA; MENDES, 2001).

Quanto ao sofrimento, ele emerge dos conflitos entre os indivíduos e a organização do trabalho, ou seja, surge quando o rearranjo da organização não é mais viável e os trabalhadores esgotam suas possibilidades de adaptação espontânea da atividade profisional às suas características individuais, fazendo a energia pulsional que encontrava descarga no trabalho acumular-se no aparelho psíquico e provocar sentimentos de desprazer e tensão (TORRES; ABRAHÃO, 2006).

Para Tschiedel e Monteiro (2013), o sofrimento no trabalho é inevitável, pois o sujeito está na presença do inesperado e pode vir a ter uma sensação de fracasso e incapacidade. Assim, ao se deparar com a realidade do trabalho, o profissional passa a vivenciar sofrimento e começa a produzir soluções que lhe permitam dar conta das tarefas prescritas (SANTOS JÚNIOR; MENDES; ARAUJO, 2009). Em síntese, mas não necessariamente para o ambiente acadêmico - foco do presente trabalho -, as vivências de sofrimento aparecem associadas à divisão e à padronização de tarefas, com subutilização do potencial técnico e da criatividade, com rigidez hierárquica, excesso de procedimentos burocráticos, centralização de informações, falta de participação nas decisões, não reconhecimento, pouca perspectiva de crescimento profissional etc. (FERREIRA; MENDES, 2001).

Contudo, é importante destacar que o sofrimento não se manifesta de maneira única para todos os indivíduos: o ele sofrimento é para um não é necessariamente para outro, mesmo quando as pessoas estão submetidas às mesmas condições ambientais adversas (BRANT; MINAYO-GOMEZ, 2004; ASSIS; MACEDO, 2008). Ademais, a abordagem baseada nas ideias de Dejours, ao mesmo tempo em que considera o sofrimento uma vivência primordial da relação do humano com o seu trabalhar, também salienta a possibilidade de tal sofrimento transformar-se em prazer. Isso é alcançado com a construção da identidade e a realização de si, por meio da dinâmica do reconhecimento (GOMES et al., 2011). 
O trabalho pode ser fonte de prazer quando se permite aplicar a inteligência e se reconhece a importância desta para a organização laboral (TSCHIEDEL; MONTEIRO, 2013). Ainda nesse âmbito, quando predomina a compatibilidade entre tarefa prescrita e atividade real ou quando uma organização flexível do trabalho permite negociar ou ajustar-se às condições adversas da situação, abre-se espaço para vivências de prazer (FERREIRA; MENDES, 2001).

Estas também ocorrem quando se experimentam sentimentos de valorização e reconhecimento no trabalho, entendendo-se por valorização o sentimento de que o trabalho tem sentido e valor por si mesmo, sendo importante e significativo para a organização e a sociedade. Por reconhecimento, por sua vez, entende-se o sentimento de aceitação e admiração no trabalho, bem como a liberdade para expressar a individualidade (MENDES; TAMAYO, 2001). Ainda assim, Dejours (2012) alerta que a psicodinâmica do trabalho pode também tornar-se uma armadilha quando, dada uma identidade muito frágil, um trabalhador se torna cativo dos julgamentos de outros, como se os benefícios do reconhecimento não pudessem ser apropriados convenientemente.

Constata-se, diante do exposto, que a dialética prazer-sofrimento consiste em um constructo originado das mediações utilizadas pelos trabalhadores para manter a saúde, evitando o sofrimento e buscando alternativas para obter prazer (FERREIRA; MENDES, 2001). Essa dialética mostra que a chave para transformar sofrimento em prazer está na própria organização do trabalho, pois é possível vivenciar prazer mesmo em contextos precários, desde que a organização do trabalho ofereça condições para o trabalhador desenvolver mobilizar: a inteligência prática, o espaço público da fala e a cooperação (HOFFMANN; TRAVERSO; ZANINI, 2014).

O Quadro 3 apresenta uma breve síntese sobre os principais constructos teóricos sobre o prazer e o sofrimento. 
Quadro 3 - Principais constructos teóricos sobre o prazer e o sofrimento

\begin{tabular}{|c|c|c|}
\hline $\begin{array}{l}\text { Constructo } \\
\text { teórico }\end{array}$ & Conceitos-chave & Principais autores \\
\hline \multirow{12}{*}{ Prazer } & Possibilita a aplicação da inteligência & \multirow{12}{*}{$\begin{array}{c}\text { Tschiedel e } \\
\text { Monteiro (2013); } \\
\text { Ferreira e Mendes } \\
\text { (2001); Mendes e } \\
\text { Tamayo (2001); } \\
\text { Assis e Macedo } \\
\text { (2008); Souza e } \\
\text { Ferreira (2010); } \\
\text { Bottega e Merlo } \\
\text { (2010); Kessler e } \\
\text { Krug (2012); } \\
\text { Martins e Honório } \\
\text { (2014); } \\
\text { Gomes et al. } \\
\text { (2011). }\end{array}$} \\
\hline & Recompensa financeira & \\
\hline & Identificação com o trabalho & \\
\hline & Desenvolvimento/Crescimento profissional & \\
\hline & $\begin{array}{l}\text { Reconhece-se a importância da inteligência } \\
\text { para a organização laboral }\end{array}$ & \\
\hline & $\begin{array}{l}\text { Vivências de prazer que decorre da } \\
\text { flexibilidade na organização do trabalho e } \\
\text { permite negociar ou ajustar o sujeito às } \\
\text { condições adversas da situação }\end{array}$ & \\
\hline & Relacionamento interpessoal no trabalho & \\
\hline & Superação de desafios & \\
\hline & Sentimento de valorização & \\
\hline & Realização profissional & \\
\hline & Liberdade de expressão & \\
\hline & Reconhecimento no trabalho & \\
\hline \multirow{16}{*}{ Sofrimento } & $\begin{array}{l}\text { Conflitos entre os indivíduos e a organização } \\
\text { do trabalho }\end{array}$ & \multirow{16}{*}{$\begin{array}{l}\text { Antloga e Mendes } \\
\text { (2009); Ferreira e } \\
\text { Mendes (2001); } \\
\text { Santos Júnior, } \\
\text { Mendes e Araujo } \\
\text { (2009); Brant e } \\
\text { Minayo-Gomez } \\
\text { (2004); Assis e } \\
\text { Macedo (2008); } \\
\text { Torres e Abrahão } \\
\text { (2006); Tschiedel e } \\
\text { Monteiro (2013); } \\
\text { Bottega e Merlo } \\
\text { (2010); Kessler e } \\
\text { Krug (2012); Souza } \\
\text { e Ferreira (2010); } \\
\text { Bispo e Helal } \\
\text { (2013); Martins e } \\
\text { Honório (2014). }\end{array}$} \\
\hline & Sentimento de desprazer & \\
\hline & Sobrecarga de trabalho & \\
\hline & Sentimento de tensão & \\
\hline & Sensação de fracasso & \\
\hline & Sensação de incapacidade & \\
\hline & $\begin{array}{l}\text { Subutilização do potencial técnico e da } \\
\text { criatividade }\end{array}$ & \\
\hline & Adoecimento & \\
\hline & Rigidez hierárquica & \\
\hline & Limitação de recursos e de espaço & \\
\hline & Excesso de procedimentos burocráticos & \\
\hline & Centralização de informações & \\
\hline & Falta de participação nas decisões & \\
\hline & Estratégias defensivas & \\
\hline & Não reconhecimento & \\
\hline & Pouca perspectiva de crescimento profissional & \\
\hline
\end{tabular}

Fonte: elaborado pelos autores (2015).

Finalmente, vale destacar, como já apontado na introdução, as principais áreas de aplicação de trabalhos relacionados à dialética prazer-sofrimento. O Quadro 4 apresenta uma síntese desses trabalhos. 
Quadro 4 - Principais áreas de aplicação dos trabalhos sobre prazer e sofrimento

\begin{tabular}{|c|c|}
\hline Aplicação & Autores \\
\hline Trabalhadores do segmento penitenciário & Tschiedel e Monteiro (2013) \\
\hline Agentes de limpeza pública & Gomes e Oliveira (2013) \\
\hline $\begin{array}{c}\text { Vendedores de uma empresa de material de } \\
\text { construção }\end{array}$ & Antloga e Mendes (2009) \\
\hline Componentes de uma banda de blues & Assis e Macedo (2008) \\
\hline Funcionários de atendimento ao público & Ferreira e Mendes (2001) \\
\hline Atividade de teleatendimento & Torres e Abrahão (2006) \\
\hline Empresa de abastecimento e saneamento & Mendes e Tamayo (2001) \\
\hline Trabalhadores de enfermagem & Kessler e Krug (2012) \\
\hline Trabalhadores de enfermagem & Martins, Robazzi e Bobroff (2010) \\
\hline Profissionais de saúde & Souza e Ferreira (2010) \\
\hline Educadores sociais & Bottega e Merlo (2010) \\
\hline Professores & Siliva.F.G. $(2011)$ \\
\hline Mestrandos em administração Helal (2013) & Martins e Honório (2014) \\
\hline Docentes de ensino superior & Giongo, Monteiro e Sobrosa (2017) \\
\hline Suinocultores &
\end{tabular}

Fonte: elaborado pelos autores (2015)

Logo, percebem-se: a grande difusão dos estudos com essa temática e sua vasta aplicação. No entanto, ainda há escassez de estudos voltados para a área de educação, principalmente em nível de pós-graduação. Além disso, este estudo ganha relevância quando se leva em consideração o problema específico que ele se propõe compreender, qual seja, a subjetividade da relação de prazer e sofrimento de mestrandos e doutorandos em administração com seu trabalho acadêmico.

\section{ASPECTOS METODOLÓGICOS}

A presente pesquisa tem como objetivo compreender a subjetividade da relação de prazer e sofrimento de mestrandos e doutorandos em administração com seu trabalho acadêmico. Classifica-se como descritiva, pois teve como principal objetivo descrever algo (MALHOTRA, 2006). Possui delineamento de estudo de caso por se tratar de uma investigação empírica voltada a uma situação no seu contexto, procurando respostas a perguntas do tipo "como" e "por quê" (YIN, 2005).

Um estudo de caso permite preservar as características holísticas e significativas dos acontecimentos da vida real, sendo usado ao lidar-se deliberadamente com condições contextuais, acreditando que estas podem ser altamente pertinentes ao fenômeno em estudo 
(YIN, 2005). Para esta pesquisa, a estratégia foi utilizada tendo em vista o objetivo de analisar o fenômeno da relação de prazer e sofrimento de mestrandos e doutorandos no contexto acadêmico.

Além disso, diante dos quatro tipos básicos de estudo de caso apontados por Yin (2005), o presente estudo é classificado como de caso único holístico, pois envolveu uma unidade única de análise e um único caso, cuja unidade social de estudo foi um curso de pós-graduação em administração de uma instituição de ensino localizada em Natal/RN. O nome foi mantido em sigilo por questões de confidencialidade.

Os dados foram coletados pessoalmente, através de entrevistas, armazenadas em um gravador de voz, com os discentes de mestrado e doutorado do curso. A técnica utilizada para coleta de dados foi a entrevista focalizada, na qual estímulos visuais são apresentados para estudar o impacto deles sobre o entrevistado, com base em um guia de entrevistas (FLICK, 2009). No caso do presente estudo, foram utilizadas quatro imagens (A, B, C e D) como estímulos visuais (Figura 1).

Figura 1 - Imagens utilizadas no estudo
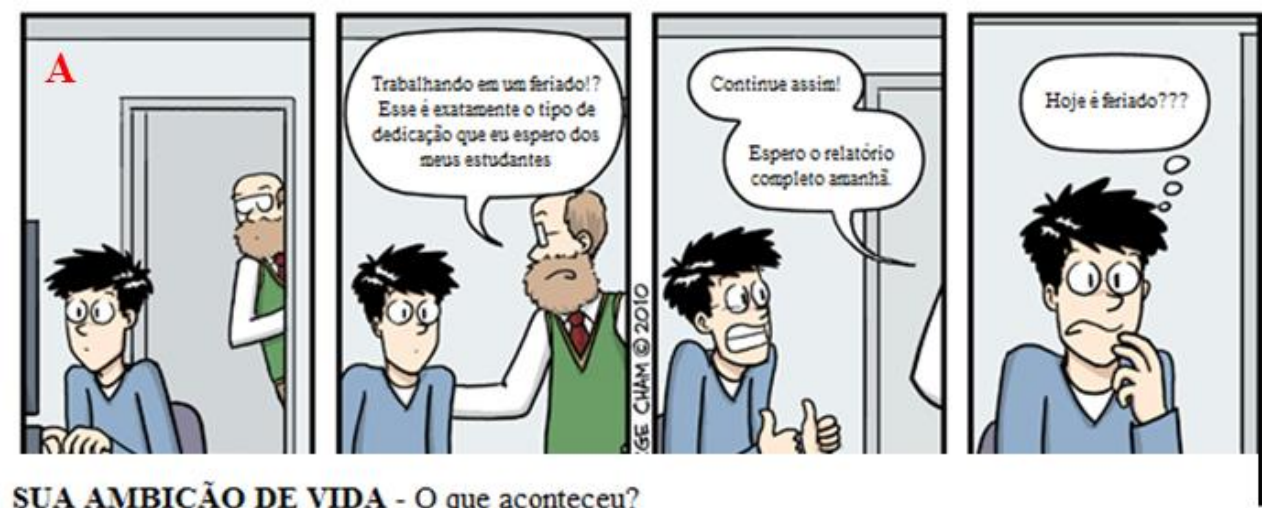

SUA AMBIÇÃO DE VIDA - O que aconteceu?
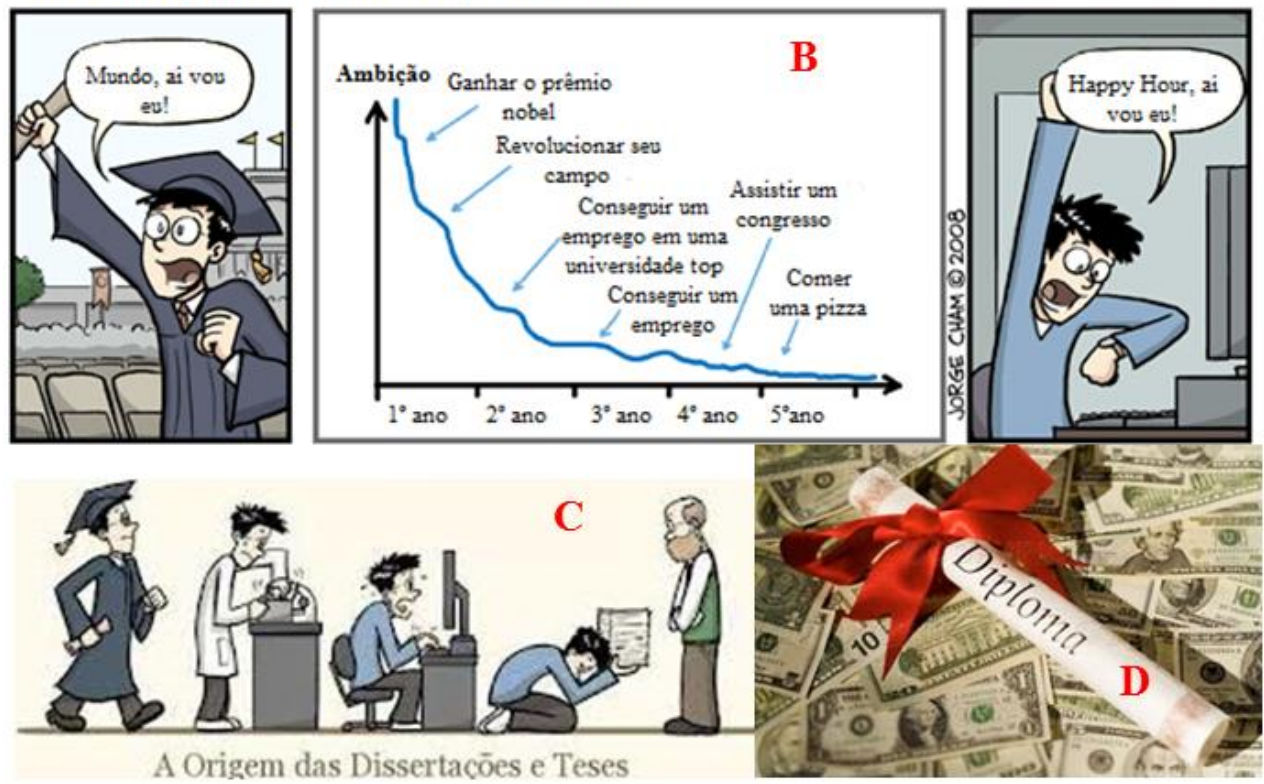

Fonte: adaptado de Hypescience (2008) e PhD Comics (2014). 
Além disso, também foram elaboradas algumas questões direcionadoras (Quadro 5) como guia das entrevistas, conforme sugere Flick (2009) para as entrevistas focalizadas. Vale salientar que estas foram apenas algumas das questões utilizadas no estudo, com o propósito de estimular respostas dos entrevistados, mas várias outras surgiram durante as entrevistas e foram utilizadas de acordo com o contexto de cada uma delas.

Quadro 5 - Questões direcionadoras

Em sua opinião, existe alguma relação entre esta imagem e a sua trajetória acadêmica do mestrado/doutorado?

O que esta imagem representa para você na realidade acadêmica do mestrado/doutorado?

Em sua opinião, esta imagem está atrelada ao prazer ou ao sofrimento em sua jornada acadêmica do mestrado/doutorado?

Em sua opinião, a sua jornada no mestrado/doutorado segue a lógica que a imagem transparece?

Fonte: dados da pesquisa (2015).

Após a definição das imagens e das questões direcionadoras, realizou-se um pré-teste, com duração de 25 minutos, como forma de analisar os instrumentos selecionados. Após essa etapa, foram realizados ajustes e procedeu-se às entrevistas.

Foram feitas quatro entrevistas, selecionadas por conveniência - variante da amostragem intencional (PATTON, 2002) -, sendo quatro com estudantes de mestrado e quatro com doutorandos, com o intuito de comparar os dois níveis acadêmicos quanto à relação entre prazer e sofrimento no exercício do trabalho acadêmico. Isso pode reduzir o esforço na amostragem, sendo às vezes a única maneira de realizar um estudo com recursos de tempo limitados e com dificuldades para aplicar uma estratégia mais sistemática da amostragem.

Vale destacar que, dadas as possibilidades teoricamente ilimitadas de uma maior integração de entrevistas, Flick (2009) afirma a necessidade de definir quando interromper a integração de casos adicionais. Dessa forma, utilizou-se o critério de saturação teórica, segundo o qual se interrompe a coleta de casos quando se atingem as informações sobre uma categoria ou grupo de casos (ou seja, quando não surgir mais nada novo). Sobre isso, percebeu-se que a saturação da presente pesquisa foi atingida na quarta entrevista de ambos os casos (mestrandos e doutorandos), tendo em vista a repetição das informações fornecidas pelos discentes, o que justifica interromper a coleta de novos casos. O Quadro 6 detalha características das entrevistas. 
Quadro 6 - Detalhamento das entrevistas realizadas

\begin{tabular}{|c|c|c|c|c|c|c|}
\hline Entrevistado & Sexo & Idade & $\begin{array}{c}\text { Tempo de } \\
\text { curso }\end{array}$ & $\begin{array}{c}\text { Duração da } \\
\text { entrevista }\end{array}$ & Meio & $\begin{array}{c}\text { Quantidade de } \\
\text { páginas }\end{array}$ \\
\hline M1 & Feminino & 23 & $\begin{array}{c}1 \text { ano } \\
20 \text { minutos }\end{array}$ & Presencial & 7 \\
\hline M2 & Masculino & 28 & $\begin{array}{c}1 \text { ano e 5 } \\
\text { meses }\end{array}$ & 18 minutos & Presencial & 5 \\
\hline M3 & Masculino & 25 & $\begin{array}{c}1 \text { ano e 3 } \\
\text { meses }\end{array}$ & 20 minutos & Presencial & 5 \\
\hline M4 & Feminino & 24 & $\begin{array}{c}1 \text { ano e 3 } \\
\text { meses }\end{array}$ & 21 minutos & Presencial & 6 \\
\hline D1 & Masculino & 24 & $\begin{array}{c}1 \text { ano e 1 } \\
\text { mês }\end{array}$ & 21 minutos & Presencial & 5 \\
\hline D2 & Masculino & 33 & $\begin{array}{c}3 \text { anos e 3 } \\
\text { meses }\end{array}$ & 25 minutos & Presencial & 7 \\
\hline D3 & Feminino & 26 & $\begin{array}{c}2 \text { anos e 3 } \\
\text { meses }\end{array}$ & 20 minutos & Presencial & 5 \\
\hline D4 & Feminino & 38 & $\begin{array}{c}3 \text { anos e 3 } \\
\text { meses }\end{array}$ & 28 minutos & Presencial & 8 \\
\hline
\end{tabular}

Fonte: dados da pesquisa (2015).

A análise dos dados foi feita de forma qualitativa, que segundo Merriam (2002) visa descobrir e compreender um fenômeno, um processo, ou as perspectivas e visão de mundo das pessoas nele envolvidas. Como defende Malhotra (2006), objetiva proporcionar uma melhor visão e compreensão do contexto de um problema. Para analisar o material, utilizou-se o software de apoio à análise qualitativa Nvivo® 10. A utilização de programas de análise de dados proporciona ao pesquisador um modo estruturado de administrar aspectos da análise qualitativa, mudando não somente como os dados qualitativos são coletados, mas também possibilitando novas formas de analisá-los (GIBBS, 2009).

Como método de interpretação dos dados, empregou-se a análise de conteúdo do tipo categorial temática. Essa modalidade propõe descobrir os núcleos de sentido que compõem uma comunicação cuja presença/frequência signifiquem alguma coisa para o objetivo analítico visado e funciona em etapas, desmembrando o texto em unidades e em categorias para reagrupamento analítico posterior (MINAYO, 1998).

São três as fases: 1) pré-análise; 2) exploração do material; e 3) tratamento dos resultados, inferência e interpretação (BARDIN, 2011). Na pré-análise, foram aprofundados os aspectos teóricos relacionados à pesquisa; na exploração do material, fez-se a codificação das entrevistas; finalmente, na fase de tratamento dos resultados, inferência e interpretação, realizou-se uma análise comparativa (GIBBS, 2009), na qual "não se observa o caso como um todo, nem toda sua complexidade; em vez disso, observa-se a multiplicidade de casos relacionados a determinados excertos" (FLICK, 2009, p. 135). Com isso, buscou-se avaliar as similaridades e dissimilaridades existentes entre os mestrandos e doutorandos quanto à 
subjetividade da relação de prazer e sofrimento deles com seu trabalho acadêmico.

Sobre o procedimento utilizado na fase de exploração do material, foi adotada a codificação baseada em conceitos. Nela, segundo Gibbs (2009), os códigos ou conceitos podem vir da literatura, de entrevistas, de percepções sobre o que está acontecendo, dentre outros. Foram realizadas três rodadas de codificação, visando extrair e definir da melhor forma as categorias de análise, bem como o número de referências para cada categoria. Encontraram-se, ao final de todas as rodadas, 159 referências, em que os estudantes de mestrado somaram 58 referências e os de doutorado, 111.

No capítulo 4 do presente estudo, as categorias de análise dos dados advindas do levantamento da literatura são utilizadas como base para analisar quais realmente afetaram os entrevistados. Além disso, também com base em tais categorias, avaliaram-se novas informações emergentes dos dados da pesquisa.

Por fim, em relação à ética na pesquisa, foram adotados nomes fictícios para cada um dos entrevistados (mestrandos identificados como M1, M2, M3 e M4 e doutorandos como D1, D2, D3 e D4), preservando sua identidade. No ato da entrevista, entregou-se um termo de consentimento escrito, informando aos entrevistados que se tratava de uma pesquisa de cunho acadêmico, na qual o anonimato seria mantido, conforme sugerido por Gibbs (2009). Ademais, o termo solicitou a autorização dos entrevistados para utilizar a entrevista para fins de pesquisa. Também no ato da entrevista, ressaltou-se sua confidencialidade.

\section{ANÁLISE DOS RESULTADOS}

Para melhor compreender os resultados obtidos neste estudo, optou-se por dividir o capítulo de resultados em duas seções: 4.1 Análise geral dos resultados; e 4.2 Análise comparativa entre mestrandos e doutorandos. A primeira seção apresenta os resultados de forma holística, analisados e contrastados com a literatura da área. A segunda seção, por seu turno, trata da análise comparativa específica entre dados dos mestrandos e doutorandos, apresentando as semelhanças e diferenças entre eles.

\subsection{Análise geral dos resultados}

Os resultados obtidos com as entrevistas foram condensados e analisados de forma 
unificada, promovendo a comparação com demais estudos da área. Os mestrandos e doutorandos relataram um total de oito códigos de sofrimento e seis de prazer.

Considerando o Quadro 3 anteriormente apresentado, que detalha os códigos levantados teoricamente e utilizados neste estudo, tem-se que, dos 28 códigos identificados na teoria (16 de sofrimento e 12 de prazer), 12 afetaram os entrevistados. Outros dois códigos citados emergiram dos dados da pesquisa: dificuldade financeira e crescimento intelectual.

Em termos gerais, pode-se inferir que os códigos de sobrecarga de trabalho, adoecimento e sentimento de desprazer foram os mais citados em relação ao sofrimento, enquanto os códigos de reconhecimento do trabalho e de relacionamento interpessoal no trabalho foram os mais citados em relação ao prazer. Sobre esses resultados, o código de sobrecarga do trabalho está atrelado à questão da realização de muitas tarefas simultaneamente. Sobre isso, há as falas de dois dos entrevistados:

Eu acho que essa parte de ficar até tarde estudando de madrugada ou então de acordar muito cedo, de renunciar algumas coisas, porque você tem que renunciar, você não vai conseguir fazer tudo ao mesmo tempo [...] Renunciar a família, seus amigos. É [...] os seus próprios hobbies, as próprias coisas que você gosta de fazer, porque você não tem tempo. Porque você tem que estudar até tarde porque o orientador tá me cobrando aquilo ou chegou um e-mail da revista que eu tenho que mandar essa comunicação ou então cumprir um prazo [M1].

Tenho percebido que estou em falta na minha casa, de estar com meus filhos, minha família [...] Eu ainda tento conciliar, mas os deveres do doutorado e as obrigações no trabalho me consomem todo o tempo [...] Acredito que esse aspecto seja minha principal dificuldade, sofrimento [D4].

Foi perceptível que esse fator foi ainda mais relevante para os doutorandos, neste caso mais velhos e com famílias constituídas, e para mestrandos que não possuem dedicação exclusiva ao curso.

A sobrecarga de trabalho também foi apontada como sofrimento para docentes, conforme estudo de Martins e Honório (2014), e para agentes de segurança penitenciária, conforme estudo de Tschiedel e Monteiro (2013). Sobre o último, os autores constataram que muitos dos agentes tinham de trabalhar em carga dupla horária, em virtude de necessidades financeiras, por exemplo. Quanto ao sentimento de desprazer, os entrevistados citaram vários fatores que levam a ele, a exemplo de realizar tarefas externas à própria área, estudar em feriados e finais de semana - gerando distanciando da família - e ter medo. Sobre este último, em especial, há os seguintes trechos: 
O medo de não conseguir é outro fator de sofrimento. Medo da reprovação, medo de [...] após afastamento [...] se eu for reprovado [...] se eu não conseguir terminar o doutorado [...] ter que restituir os valores mensais do meu trabalho pra União [...] [D2]

Essa figura é um retrato do meu primeiro ano de mestrado [...] lembro que não consegui aproveitar nenhum feriado completamente, sempre tinha algo a fazer [...] quando me livrava de alguma tarefa [...] artigo ou algo assim [...] já me lembrava de outra atividade e outra e outra [...] [M4]

A incidência desse sentimento foi mais exacerbada justamente para o doutorando que estava em período final de desenvolvimento da tese. Alguns outros autores apontaram o mesmo fator de sofrimento, a exemplo de Antloga e Mendes (2009), investigando vendedores de uma empresa de material de construção. Estes tinham medo de errar, de emitir opiniões, de ser vítimas de "fofoca" de colegas ou, mesmo, de ser demitidos. Numa análise mais próxima da apresentada no presente estudo, Bispo e Helal (2013) apontaram que mestrandos em administração desenvolveram esse sentimento muito em virtude das pressões da academia sobre os alunos, ressaltando inclusive que, na pós-graduação do Brasil, o sistema de avaliação é centrado no produtivismo.

A questão do adoecimento surgiu em virtude da sobrecarga de trabalho supracitada. Conforme os entrevistados revelaram, sentimentos como falta de vontade de trabalhar, dificuldade de dormir e dores nas costas passaram a ser frequentes em suas rotinas. Os seguintes trechos demonstram isso:

Chegou uma hora que acordar cedo para ir a aula era um sacrifício [...] ainda mais quando eu havia passado a madrugada toda fazendo um artigo ou lendo algum material para a aula [...] isso quando eu não acordava com dores nas costas por ter passado muito tempo sentado escrevendo [...] até pensar em como eu cheguei nesse nível de [...] tão novo e já com dores nas costas [...] me fez refletir sobre se é isso que eu realmente quero para meu futuro [M3]

Comentei com alguns colegas de turmas como tenho dificuldades de dormir, parece que minha cabeça não descansa [...] muitos riram para não chorar, como dizemos aqui [...] e também revelaram já terem passado por situações semelhantes [...] de certa forma me deu um alívio momentâneo [...] afinal, não acontece apenas comigo [D4]

Percebeu-se que essa questão é presente para ambos os níveis e, como colocam Tschiedel e Monteiro (2013), decorre do fato de o trabalho deixar de ser motivo de prazer, bemestar e satisfação, passando a ser lugar de dor, sofrimento e cansaço. Anchieta et al. (2011), em estudo com policiais civis, apontam essa questão como relevante para o trabalho dos mesmos, 
que, em tais situações, os profissionais continuam trabalhando e, quando se encontram fisicamente impossibilitados, como no caso de cirurgias, não possuem acesso à rede de proteção social do Estado.

Além desses três principais códigos citados sobre sofrimento com maior frequência, cabe ainda destacar outro: o não reconhecimento. Segundo Dejours (1999), a dinâmica do reconhecimento é de fundamental importância para que o sofrimento no trabalho ganhe sentido e possa se transformar em prazer. Trata-se de um aspecto bastante encontrado nos estudos da área e em diferentes situações. Assis e Macedo (2008) e de Gomes e Oliveira (2013), por exemplo, abordam componentes de uma banda de blues e agentes de limpeza pública, respectivamente. Também se podem citar Kessler e Krug (2012), estudo com trabalhadores de enfermagem, e Martins e Honório (2014), pesquisa com docentes, o que mostra quão diversificadas são as áreas em que esse código é presente. Para o caso do presente estudo, o não reconhecimento está atrelado à cobrança da própria família, desvalorizando a atividade, como é descrito no seguinte trecho:

[...] minha família não entendia tão bem [...] o sentido da pós-graduação [...] uma família humilde [...] então assim [...] difícil de você explicar qual era o sentido disso e fica sempre aquela cobrança: ah, não vai trabalhar não? Vai ficar só estudando? [D1]

Esse fator tem peso especial para os estudantes sem vínculo empregatício, cujas famílias não enxergam, de forma clara e palpável, o possível retorno da atividade que eles desenvolvem. Isso foi constatado, por exemplo, por Bispo e Helal (2013), que relatam a incompreensão sobre a importância do mestrado.

Quanto aos principais códigos apontados sobre o prazer, destaca-se o relacionamento interpessoal no trabalho, que no presente estudo apresentou um aspecto um pouco diferente daqueles encontrados em outros trabalhos. Assim, em estudos como o de Gomes e Oliveira (2013) e Bispo e Helal (2013), o aspecto apareceu ligado à cooperação solidária entre os colegas. Apesar de essa ligação também ter sido encontrada no presente estudo, a grande parte das citações relacionadas se deram em razão da relação entre estudante e orientador. Foram citadas relações de amizade fora do ambiente profissional e mesmo familiar, como se pode observar nos seguintes trechos:

A minha relação com meu orientador é boa. Eu tenho uma relação tanto acadêmica quanto de amizade com ele [...] de ir na casa dele, de sair com ele, tomar cerveja junto [...] risos [D1] 


\begin{abstract}
Minha relação com meu orientador é uma relação de pai para filho [D2]
Meu orientador é quase da família, se juntarmos o mestrado com o doutorado, já são o que [...] mais de quatro anos trabalhando juntos [...] sempre brincamos que nossa relação já está durando mais que muitos casamentos por aí $[\ldots]$ risos [D3]
\end{abstract}

Esse resultado se mostra de grande importância, pois segundo Dejours (1999), trabalhar não é apenas exercer atividades produtivas, mas também conviver. Como representado nas falas, esse sentimento foi mais destacado pelos doutorandos, por terem relações mais próximas e duradouras com seus respectivos orientadores. Neste mesmo sentido, destaca-se também o código de identificação com o trabalho, que geralmente está mais relacionado ao gostar da sua atividade, como apontado nos estudos de Assis e Macedo (2008), Tschiedel e Monteiro (2013) e de Gomes e Oliveira (2013). Isso está claramente apresentado no seguinte trecho:

Quando eu estou lá, de madrugada, lendo e tal, não é por uma coisa que eu não goste. Se eu não gostasse, eu não estava fazendo! Se eu não gostasse eu estaria dormindo que seria muito mais legal do que estar lá. [...] eu tô fazendo alguma coisa que eu gosto, que eu almejo, que eu tenho um objetivo, um ideal [...] [D2]

Finalmente, cabe destacar também os dois códigos que emergiram neste estudo, quais sejam: dificuldade financeira (sofrimento) e crescimento intelectual (prazer). O primeiro geralmente está atrelado ao prazer (como recompensa financeira), como reportado no estudo de Tschiedel e Monteiro (2013), mas, para o caso deste estudo, revelou-se como fator de sofrimento. Ele estava relacionado à situação de desemprego e de falta de bolsa de pósgraduação, o que interferia na realização das tarefas. Por sua vez, o código de crescimento intelectual foi citado em relação ao próprio amadurecimento intelectual resultante da atividade acadêmica e ao crescimento ao longo do percurso, como descrito no trecho a seguir:

[...] é prazeroso quando você chega no final do percurso e [...] vê o que conseguiu realizar e que você mudou bastante, amadureceu, aprendeu no meio do percurso [M2]

Feita essa análise holística dos dados, com exemplos e citações de trabalhos da área, a seção 4.2 tratará especificamente das diferenças e semelhanças entre as duas categorias de estudantes investigadas. 


\subsection{Análise comparativa entre mestrandos e doutorandos}

Foram elaboradas as figuras 2 e 3, que apresentam, respectivamente, que categorias e códigos de prazer e sofrimento foram mencionadas pelos mestrandos e quais, pelos doutorandos. Os códigos citados e marcados de azul emergiram dos dados, e o tamanho vertical das caixas dos códigos está diretamente proporcional ao número de citações dos entrevistados.

Figura 2 - Categorias e códigos do prazer e sofrimento citados pelos mestrandos

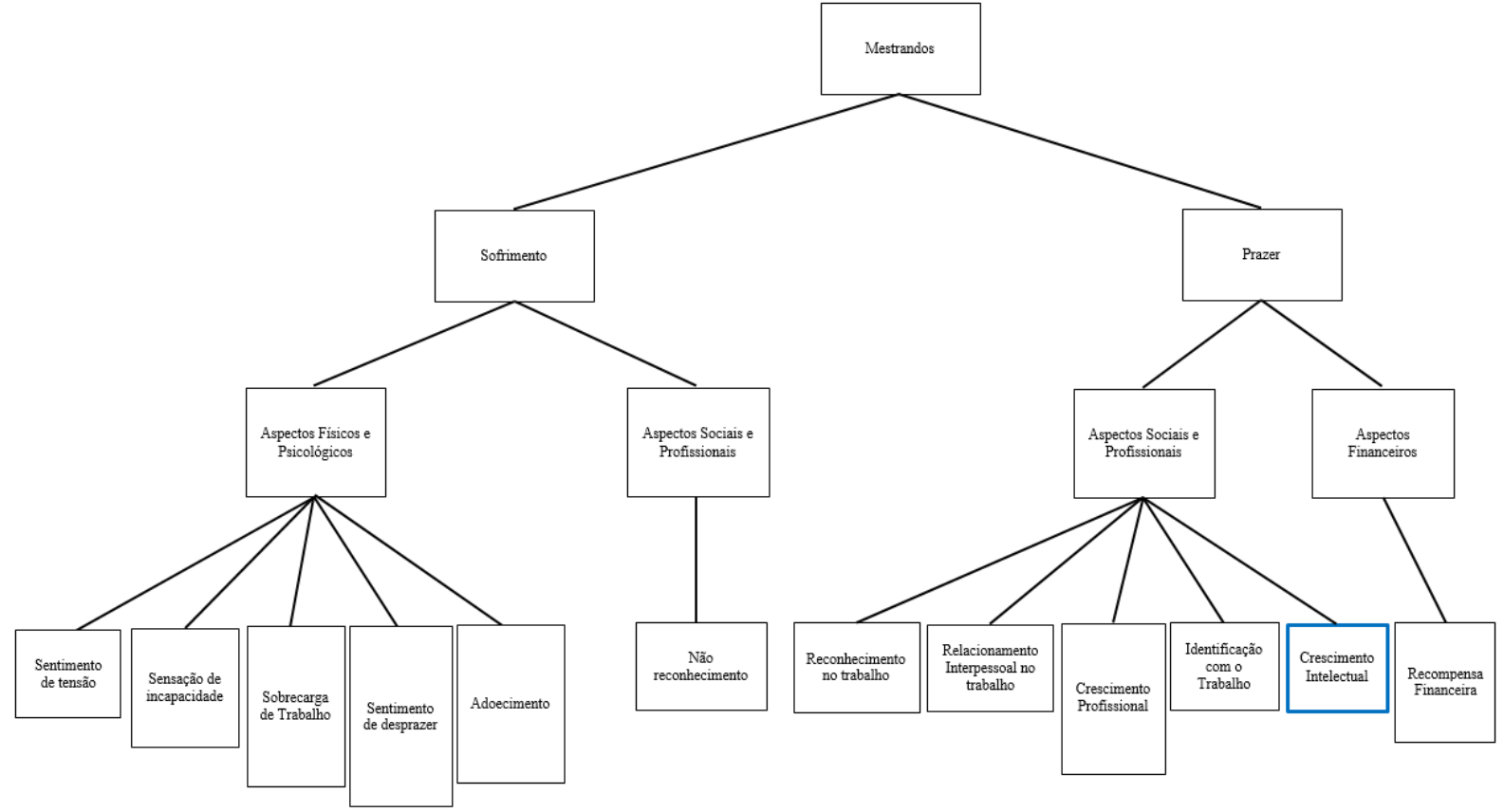

Fonte: elaborado pelos autores (2015).

Figura 3 - Categorias e códigos do prazer e sofrimento citados pelos doutorandos

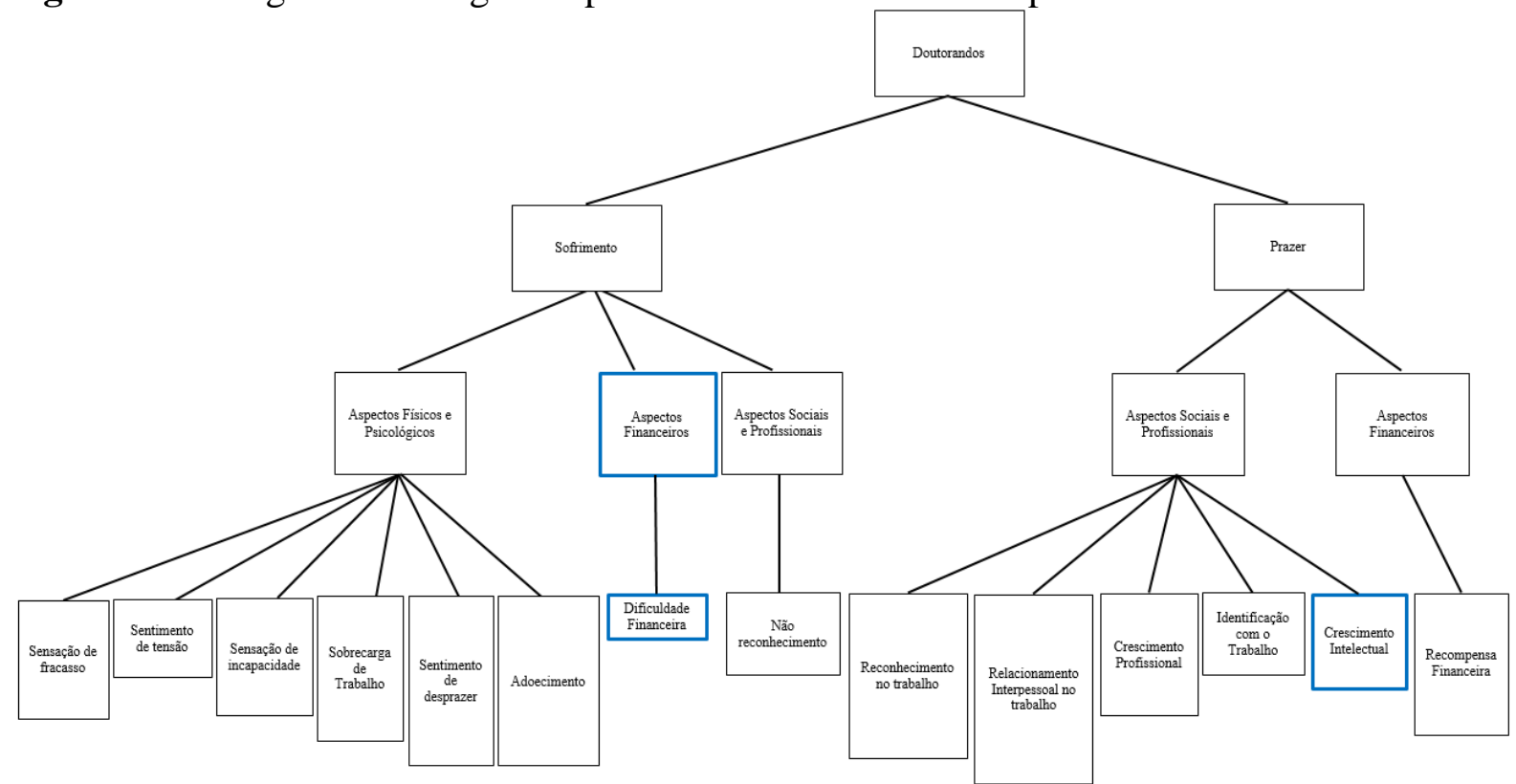

Fonte: elaborado pelos autores (2015). 
Conforme exposto nas imagens, os mestrandos citaram, ao todo, seis códigos relacionados ao sofrimento, sendo o sentimento de desprazer o mais frequente, e seis códigos relacionados ao prazer, sendo o crescimento profissional o de maior destaque. Resultado similar ocorreu com os doutorandos, que citaram, ao todo, oito códigos relacionados ao sofrimento, sendo o sentimento de desprazer e o adoecimento os mais frequentes, e seis códigos relacionados ao prazer, sendo o relacionamento interpessoal no trabalho o mais frequente.

Com base no exposto, percebe-se que os doutorandos apontaram uma maior diversidade de situações de sofrimento em sua atividade (mais códigos citados) e apontaram o relacionamento interpessoal com seus colegas e com seus orientadores como a melhor estratégia para lidar com essas situações. Os mestrandos, assim como doutorandos, apontaram que o sentimento de desprazer é o principal sofrimento em sua atividade, mas, diferentemente dos doutorandos, a principal estratégia utilizada para lidar com esse sofrimento é a própria ambição de futuro, vislumbrada com base no título que suas atividades lhes proporcionarão.

Assim, pode-se inferir que os doutorandos se apegam mais à união e ao coleguismo entre seus pares e com seus respectivos orientadores, enquanto os mestrandos, em um projeto mais individualista, se apegam mais às próprias ambições. Tais resultados podem ser entendidos na medida em que os doutorandos geralmente já possuem um vínculo formado com seus colegas e orientadores advindos do mestrado, assim como muitos deles já são professores e profissionais da área, algo que os mestrandos ainda vislumbram. Além disso, os mestrandos ainda se encontram em uma posição de indefinição sobre seu futuro, tanto em relação à carreira profissional, quanto a um possível doutorado.

Visando a uma análise mais aprofundada dos resultados, as figuras 4 e 5 apresentam, respectivamente, as 50 palavras mais citadas por mestrandos e as 50 mais citadas por doutorandos. O tamanho de cada palavra é proporcional à incidência das falas dos entrevistados. 
Figura 4 - Palavras mais citadas pelos mestrandos

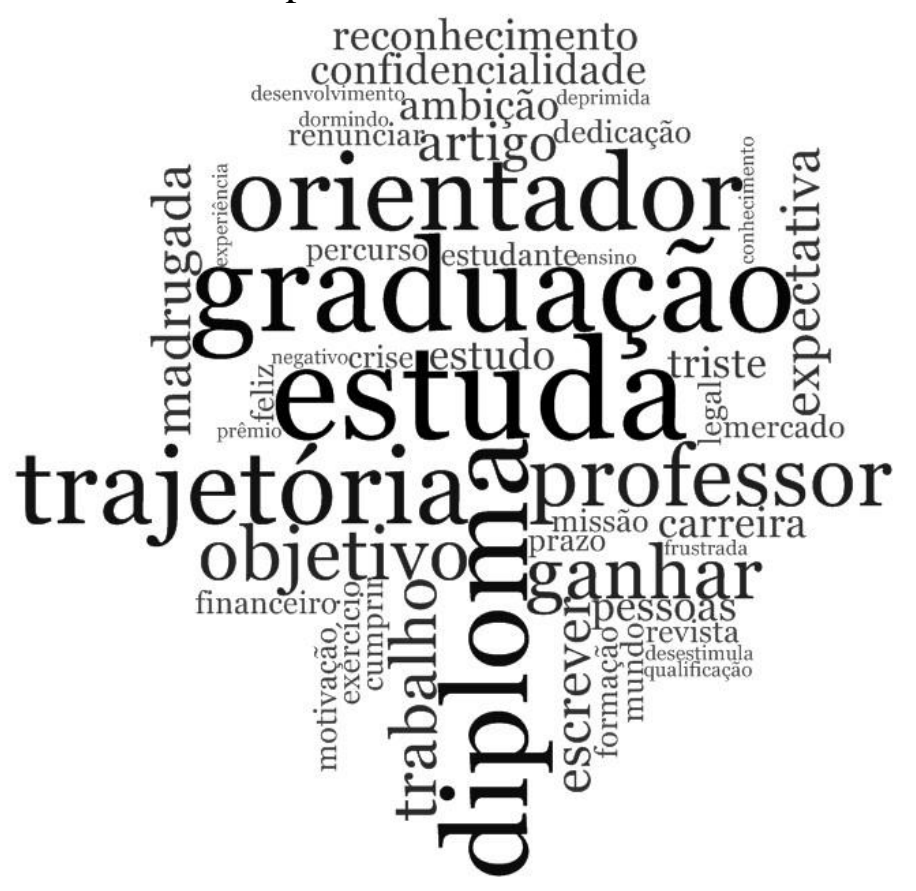

Fonte: elaborado pelos autores (2015).

Figura 5 - Palavras mais citadas pelos doutorandos

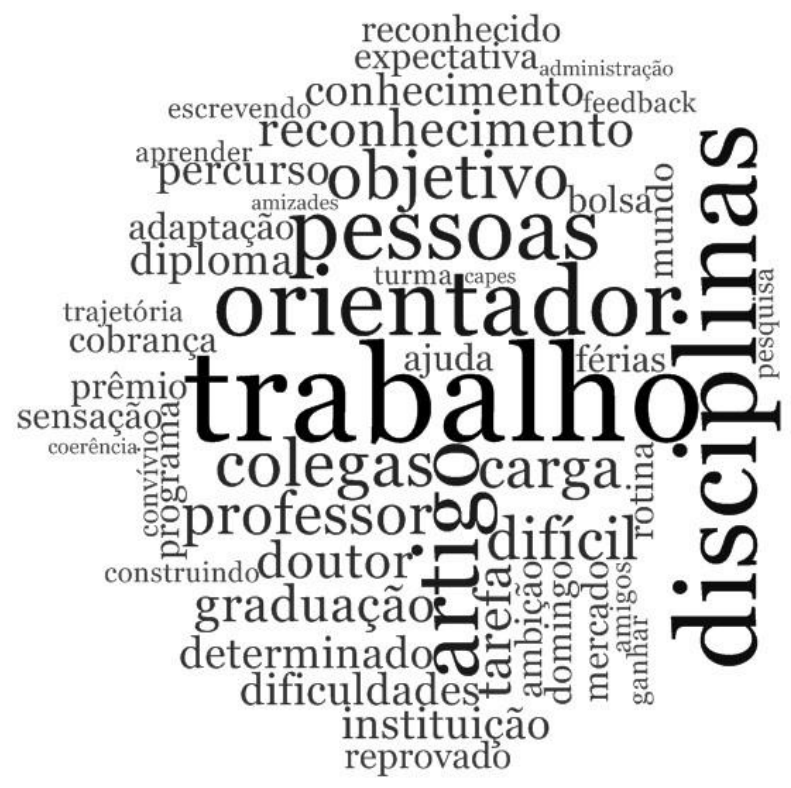

Fonte: elaborado pelos autores (2015).

Analisando ambas as nuvens de palavras, percebem-se claramente as diferenças entre os mestrandos e doutorandos. Aqueles citaram bastante algumas palavras como "orientador" e "graduação", ligadas diretamente ao choque de realidade por eles vivido, em relação tanto à exigência do mestrado maior do que a da graduação, quanto à proximidade da figura do orientador, indissociável da questão da cobrança e exigência. Para lidar com essas situações, as 
principais estratégias dos mestrandos são elaborar planos e cronogramas de estudos, bem como tentar aproximar-se de outros discentes orientados por seus orientadores, principalmente aqueles do doutorado, como forma de conseguir entender as formas de trabalho e os níveis de exigência dos respectivos docentes.

Além dessas, também é interessante mencionar as palavras “diploma" e "ganhar", que também aparecem com destaque na nuvem. Como já citado, em muitos casos, a principal motivação para realizar o mestrado é o objetivo de longo prazo de conseguir um diploma, que poderá se traduzir em uma melhoria financeira.

Por conta da ansiedade gerada em relação aos aspectos supracitados, principalmente relacionado a uma melhoria financeira futura com o título, os mestrandos geralmente se utilizam da estratégia por eles chamada de "pés no chão", ou seja, vislumbrar um futuro melhor, mas traçar metas de curto prazo e conseguir alcançar esse objetivo com pequenas conquistas. Dessa forma, eles acreditam evitar frustações.

Para os doutorandos, por sua vez, a principal palavra citada foi "trabalho", fato explicado pelo acúmulo do doutorado com outras funções. Como os doutorandos geralmente já possuem um vínculo empregatício, o percurso acaba sendo mais difícil. Isso explica por que os doutorandos citaram mais códigos diferentes de sofrimento e por que palavras como "disciplinas" e "artigo" também foram expressivas, tendo em vista a dificuldade para realizar as atividades da pós-graduação e as demais funções. Além disso, também como já mencionado, palavras como "pessoas", "colegas" e "orientador" apresentaram certo destaque, tendo em vista que a amizade e o coleguismo são as principais estratégias utilizadas contra o sofrimento.

\section{CONSIDERAÇÕES FINAIS}

Este estudo buscou compreender a subjetividade da relação entre prazer e sofrimento de mestrandos e doutorandos em administração com seu trabalho acadêmico. Nesse sentido, podese considerar que o objetivo foi atingido, apesar das limitações da pesquisa em relação à especificidade da aplicação.

As principais contribuições trazidas com o trabalho foram as de reforçar e ratificar aspectos de prazer e sofrimento já apresentados na literatura (TSCHIEDEL; MONTEIRO, 2013; ANTLOGA; MENDES, 2009; BISPO; HELAL, 2013; ASSIS; MACEDO, 2008; 
GOMES; OLIVEIRA, 2013; KESSLER; KRUG, 2012), bem como de trazer novos códigos para a discussão - dificuldade financeira (sofrimento) e crescimento intelectual (prazer).

De forma geral, os códigos de sofrimento citados estavam ligados à realização de tarefas que não eram de áreas próprias, estudar em feriados e finais de semana, distanciamento da família, medo, realização simultânea de muitas tarefas e o não reconhecimento, atrelado à cobrança da própria família. Os códigos de prazer, por sua vez, estavam ligados à cooperação solidária entre os colegas, à relação com o orientador e a gostar da própria atividade.

Outra contribuição apresentada foi a análise comparativa desses aspectos em relação a mestrandos e doutorandos. Foram apontadas similaridades e dissimilaridades de ambos os perfis, consideradas importantes para entender clara e precisamente suas especificidades.

Em síntese, observou-se que os mestrandos apontaram o sentimento de desprazer como principal fonte de sofrimento e o crescimento profissional como principal fonte de prazer. Os doutorandos, por sua vez, apontaram o sentimento de desprazer e o adoecimento como principais fontes de sofrimento, e o relacionamento interpessoal no trabalho como principal fonte de prazer.

Diante desses resultados, ressalta-se como implicação gerencial do presente artigo um conjunto de elementos capazes de ser incorporados aos processos seletivos dos programas de pós-graduação em administração, tornando-os mais eficazes na definição do perfil dos candidatos, seja do mestrado ou do doutorado. Ademais, os programas também poderão atuar de forma mais adequada na resolução de problemas muitas vezes desconhecidos por eles, no intuito de apoiar os alunos de forma mais efetiva.

Adicionalmente, sugere-se realizar eventos ou ações específicas que incentivem mais o reconhecimento do trabalho acadêmico desenvolvido pelos discentes, que muitas vezes adoecem em razão da sobrecarga de trabalho e não são reconhecidos por isso. Da mesma forma, eventos, cursos ou até mesmo a instituição de tutorias poderia ajudar a diminuir o impacto da carga de trabalho gerado na transição para a pós-graduação, principalmente no caso do mestrado.

Mais uma consideração seria investir em ações que promovam o relacionamento interpessoal entre os pares, principalmente na relação estudante e orientador, já desde o início do curso, pois os resultados da pesquisa se mostraram bastante positivos em relação a esse aspecto. Já no que se refere às limitações enfrentadas na pesquisa, destaca-se a necessidade de relativizar os resultados, tendo em vista que se analisou apenas um curso de pós-graduação em 
administração na cidade de Natal/RN, sendo necessárias novas análises para incrementar a discussão e promover mais debates em torno da problemática.

Para continuidade deste trabalho, sugere-se que pesquisadores interessados comparem os tipos de pós-graduação lato sensu e stricto sensu, bem como considerem utilizar outras formas de analisar os dados, como aquela voltada a núcleos de sentido, proposta por Ferreira e Mendes (2007). Finalmente, espera-se que as contribuições deste estudo possam ser de utilidade para outros pesquisadores que desejem compreender a dialética entre prazer e sofrimento na área de pós-graduação. 


\section{REFERÊNCIAS}

ABRAHÃO, J. A loucura do trabalho. Psicologia: Ciência e Profissão, v. 10, n. 1, p. 39, 1990.

ANCHIETA, V. C. C.; GALINKIN, A. L.; MENDES, A. M. B.; NEIVA, E. R. Trabalho e riscos de adoecimento: um estudo entre policiais civis. Psicologia: Teoria e Pesquisa, v. 27, n. 2, p. 199-208, 2011.

ANTLOGA, C. S.; MENDES, A. M. Sofrimento e adoecimento dos vendedores de uma empresa de material de construção. Psicologia: Teoria e Pesquisa, v. 25, n. 2, p. 255-262, 2009.

ASSIS, D. T. F.; MACEDO, K. B. Psicodinâmica do Trabalho dos músicos de uma banda de blues. Psicologia \& Sociedade, v. 20, n. 1, p. 117-124, 2008.

ATHAYDE, M. Christophe Dejours: da psicopatologia à psicodinâmica do trabalho. Cadernos de Saúde Pública, v. 21, n. 3, p. 989-990, 2005.

BARDIN, L. Análise de conteúdo. São Paulo: Edições 70, 2011.

BISPO, A. C. K. A.; HELAL, D. H. A dialética do prazer e sofrimento de acadêmicos: Um estudo com mestrandos em administração. Revista de Administração FACES Journal, v. 12, n. 4, p. 121-136, 2013.

BOAS, A. A. V.; MORIN, E. M. Psychological Well-Being and Psychological Distress for Professors in Brazil and Canada. Revista de Administração Mackenzie, v. 15, n. 6, p. 201$219,2014$.

BOTTEGA, C. G.; MERLO, Á. R. C. Prazer e sofrimento no trabalho dos educadores sociais com adolescentes em situação de rua. Cadernos de psicologia social do trabalho, v. 13, n. 2, p. 259-275, 2010.

BOUYER, G. C. Contribuição da Psicodinâmica do Trabalho para o debate: "o mundo contemporâneo do trabalho e a saúde mental do trabalhador". Revista Brasileira de Saúde Ocupacional, v. 35, n. 122, p. 249-259, 2010.

BRANT, L. C.; MINAYO-GOMEZ, C. A transformação do sofrimento em adoecimento: do nascimento da clínica à psicodinâmica do trabalho. Ciência \& Saúde Coletiva, v. 9, n. 1, p. 213-223, 2004.

140 CONTEXTUS - Revista Contemporânea de Economia e Gestão. Vol. 16 - No 2 - mai./ago. 2018 
CASTRO, N. T.; TOLEDO, A. H. F.; ANDERY, A. M. N. Tramas do cotidiano: a Psicodinâmica do trabalho em um Conselho Tutelar1. Psicologia: ciência e profissão, v. 30, n. 3, p. 662-675, 2010.

DAL FORNO, C. A Centralidade do Sujeito na Construção de um Trabalho Vivo. Sig Revista de Psicanálise, p. 139-142, 2015.

DEJOURS, C. A banalização da injustiça social. Rio de Janeiro: Fundação Getúlio Vargas, 1999.

A carga psíquica no trabalho. Betiol MIS Centro de estudos e pesquisas do trabalho - CEPT. São Paulo: Atlas; 1994.

A loucura do trabalho: Estudo de psicopatologia do trabalho. São Paulo: CortezOboré, 1992.

Psicodinâmica do trabalho e teoria da sedução. Psicologia em Estudo, v. 17, n. 3, p. 363-371, 2012.

Subjetividade, trabalho e ação. Production, v. 14, n. 3, p. 27-34, 2004.

Trabalho vivo: trabalho e emancipação. Brasília: Paralelo 15, 2012.

; ABDOUCHELI, E. Itinerário teórico em psicopatologia do trabalho. In: ; JAYET, C. Psicodinâmica do Trabalho: contribuições da Escola Dejouriana à análise da relação prazer, sofrimento e trabalho. São Paulo: Atlas, 1994. p. 119-145.

; JAYET, C. Psicodinâmica do Trabalho - Contribuições da Escola Dejouriana à análise da relação prazer, sofrimento e trabalho. São Paulo: Atlas, 1994.

FERREIRA, M. C.; MENDES, A. M. Inventário sobre trabalho e riscos de adoecimento ITRA: Instrumento auxiliar de diagnóstico de indicadores críticos no trabalho. In: Ana Magnólia (Org.). Psicodinâmica do trabalho: teoria, método e pesquisas. São Paulo: Casa do Psicólogo, 2007. Cap. 5, p. 111-126

". Só de pensar em vir trabalhar, já fico de mau humor": atividade de atendimento ao público e prazer-sofrimento no trabalho. Estudos de Psicologia (Natal), v. 6, n. 1, p. 93-104, 2001. 
FLICK, U. Introdução à pesquisa qualitativa. 3. ed. Porto Alegre: Artmed, 2009

GIBBS, Graham. Análise de Dados Qualitativos. Porto Alegre: Artmed, 2009.

GIONGO, C. R.; MONTEIRO, J. K.; SOBROSA, G. M. R. Suinocultor: vivências de prazer e sofrimento no trabalho precário. Psicologia \& Sociedade, v. 29, e147648, p. 1-11, 2017.

GOMES, L.; MASSON, L. P.; BRITO, J. C.; ATHAYDE, M. Competências, sofrimento e construção de sentido na atividade de auxiliares de enfermagem em Utin. Trabalho, Educação e Saúde (Online), v. 9, supl. 1, p. 137-156, 2011.

GOMES, C. C.; OLIVEIRA, R. S. Agentes de limpeza pública: um estudo sobre a relação prazer/ sofrimento no ambiente laboral. Psicologia Ciência e Profissão, v. 33, n. especial, p. 138-153, 2013.

HELOANI, R.; LANCMAN, S. Psicodinâmica do trabalho: o método clínico de intervenção e investigação. Production, v. 14, n. 3, p. 77-86, 2004.

HOFFMANN, C.; TRAVERSO, L. D.; ZANINI, R. R. Contexto de trabalho das pessoas com deficiência no serviço público federal: contribuições do inventário sobre trabalho e riscos de adoecimento. Gestão \& Produção, v. 21, n. 4, p. 707-718, 2014.

HYPESCIENCE. Website Hypescience. 2008. Disponível em: $<$ http://hypescience.com/bolsas de estudos-tudo-o-que-voce-precisa-saber/> Acesso em: 10 set. 2014.

KESSLER, A. I.; KRUG, S. B. F. Do prazer ao sofrimento no trabalho da enfermagem: o discurso dos trabalhadores. Revista Gaúcha de Enfermagem, v. 33, n. 1, p. 49-55, 2012.

LANCMAN, S.; UCHIDA, S. Trabalho e subjetividade: o olhar da psicodinâmica do trabalho. Cadernos de Psicologia Social do Trabalho, v. 6, p. 79-90, 2003.

MALHOTRA, N. K. Pesquisa de Marketing: uma orientação aplicada. 4. ed. Porto Alegre: Bookman, 2006.

MARTINS, A. A. V.; HONÓRIO, L. C. Prazer e Sofrimento Docente em uma Instituição de Ensino Superior Privada em Minas Gerais. Organização \& Sociedade, v. 21, n. 68, p. 79-96, 2014. 
MARTINS, J. T.; ROBAZZI, M. L. C. C.; BOBROFF, M. C. C. Prazer e sofrimento no trabalho da equipe de enfermagem: reflexão à luz da psicodinâmica Dejouriana. Revista da escola de enfermagem da USP, v. 44, n. 4, p. 1107-1111, 2010.

MENDES, A. M.; TAMAYO, A. Valores organizacionais e prazer-sofrimento no trabalho. Psicologia USF, v. 6, n. 1, p. 39-46, 2001.

MERLO, A. R. C.; MENDES, A. M. B. Perspectivas do uso da psicodinâmica do trabalho no Brasil: teoria, pesquisa e ação. Cadernos de Psicologia Social do Trabalho, v. 12, n. 2, p. 141$156,2009$.

MERRIAM, S. B. Qualitative research in practice: examples for discussion and analysis. São Francisco: Jossey-Bass, 2002.

MINAYO, M. C. S. O Desafio do conhecimento: pesquisa qualitativa em saúde. São Paulo: HUCITEC-ABRASCO, 1998.

MOLINIER, P. Les enjeux psychiques du travail. Paris: Payot \& Rivages, 2006.

A dimensão do cuidar no trabalho hospitalar: abordagem psicodinâmica do trabalho de enfermagem e dos serviços de manutenção. Revista Brasileira de Saúde Ocupacional, v. 33, n. 118, p. 6-16, 2008.

PATTON, M. Q. Qualitative research evaluation methods. 3. ed. London: Sage, 2002.

PHD COMICS. Website do Phd Comics. 2014. Disponível em: <http://phdcomics.com/comics.php> Acesso em: 10 set. 2014.

PRADO FILHO, K.; MARTINS, S. A subjetividade como objeto da (s) psicologia (s). Psicologia \& Sociedade, v. 19, n. 3, p. 14-19, 2007.

RAMMINGER, T.; NARDI, H. C. Subjectivity and work: some conceptual contributions from Michel Foucault. Interface - Comunicação, Saúde, Educação, v. 12, n. 25, p. 339-46, 2008 .

REY, F. G. Epistemologia qualitativa y subjetividad. São Paulo: Educ, 1997.

RIBEIRO, C. V. S.; LÉDA, D. B. O significado do trabalho em tempos de reestruturação produtiva. Estudos e Pesquisa em Psicologia, v. 4, n. 2, p. 76-83, 2004. 
SANTOS JÚNIOR, A. V.; MENDES, A. M.; ARAUJO, L. K. R.. Experiência em clínica do trabalho com bancários adoecidos por Ler/ Dort. Psicologia Ciência e Profissão, v. 29, n. 3, p. 614-625, 2009.

SCOZ, B. J. L. Subjetividade de professoras/es: sentidos do aprender e do ensinar. Psicologia da Educação, n. 26, p. 05-27, 2008.

SILVA, F. G. O professor e a educação: entre o prazer, o sofrimento e o adoecimento. Revista Espaço Acadêmico, v. 11, n. 124, p. 57-66, 2011.

SILVA, N. R. Fatores determinantes da carga de trabalho em uma unidade básica de saúde. Ciência \& Saúde Coletiva, v. 16, n. 8, p. 3393-3402, 2011.

SILVA, L. A.; SANTOS, N. I. S. Subjetividade e trabalho na educação. Revista Mal-Estar e Subjetividade, v. 11, n. 4, p. 1429-1460, 2011.

SOUZA, K. M. O.; FERREIRA, S. D. Assistência humanizada em UTI neonatal: os sentidos e as limitações identificadas pelos profissionais de saúde. Ciência \& Saúde Coletiva, v. 15, n. 2, p. 471-480, 2010.

SOUZA, E. C.; RIBEIRO, D. F. Trabalho e Subjetividade: A carto (foto) grafia como método investigativo da subjetividade de trabalhadores provenientes do setor calçadista. In: ENCONTRO NACIONAL DA ABRAPSO (ENABRAPSO) 15, 2009, Maceió. Anais... Maceió: ABRAPSO, 2009.

SZNELWAR, L. I.; UCHIDA, S.; LANCMAN, S. A subjetividade no trabalho em questão. Tempo Social, revista de sociologia da USP, v. 23, n. 1, p. 11-30, 2011.

TORRES, C. C.; ABRAHÃO, J. I. A atividade de teleatendimento: uma análise das fontes de prazer e sofrimento no trabalho. Revista Brasileira de Saúde Ocupacional, v. 31, n. 114, p. 113-124, 2006.

TRAESEL, E. S.; MERLO, A. R. C. Trabalho imaterial no contexto da enfermagem hospitalar: vivências coletivas dos trabalhadores na perspectiva da Psicodinâmica do Trabalho. Revista Brasileira de Saúde Ocupacional, v. 36, n. 123, p. 40-55, 2011.

TSCHIEDEL, R. M.; MONTEIRO, J. K. Prazer e sofrimento no trabalho das agentes de segurança penitenciária. Estudos de Psicologia, v. 18, n. 3, p. 527-535, 2013. 
VERONESE, M. V. Subjetividade, trabalho e economia solidária. Revista Crítica de Ciências Sociais, n. 84, p. 153-167, 2009.

YIN, R. K. Estudo de caso: planejamento e métodos. 3. ed. Porto Alegre: Bookman, 2005. 